\title{
O PURISMO LINGÜÍSTICO NA MÍDIA BRASILEIRA NA \\ PASSAGEM DO SÉCULO XX PARA O SÉCULO XXI
}

\section{THE LINGUISTIC PURISM IN THE BRAZILIAN MEDIA IN THE TRANSITION FROM THE XX CENTURY TO THE XXI CENTURY}

\author{
Marina Célia Mendonça*
}

RESUMO: O tema desta pesquisa é o purismo lingüístico presente na mídia impressa brasileira na passagem do século XX para o século XXI. A metalinguagem purista analisada tem por temática principal o uso/ensino da norma culta e a restrição ao uso de estrangeirismos. Distinguem-se no corpus dois purismos, chamados de purismo nacionalista e purismo neoliberal. A pesquisa utiliza como base teórica para as análises realizadas os estudos bakhtinianos do discurso.

PALAVRAS-CHAVE: purismo lingüístico, análise do discurso, mídia.

ABSTRACT: The theme of this research is the linguistic purism in the Brazilian media in the transition from the XX century to the XXI century. This linguistic purism takes into consideration the use/teaching of the educated norm and the restriction to the use of foreign expressions in the country. There are, in the analyzed discourses, two types of purism, which are called neoliberal purism and nationalistic purism. The research benefited from the bakhtinian studies using the dialogism as a support for the analyses that were done.

KEY WORDS: linguistic purism, discourse analysis, media.

* Docente e pesquisadora da Universidade de Franca (UNIFRAN) e do UNI-FACEF Centro Universitário de Franca. Doutora em Lingüística. Email: m.c.mendonca@uol.com.br. 



\section{O PURISMO LINGÜÍSTICO NA MÍDIA BRASILEIRA NA PASSAGEM DO SÉCULO XX PARA O SÉCULO XXI}

\section{Introdução}

Neste artigo, analisa-se a metalinguagem purista presente nas mídias brasileiras na passagem do século XX para o século XXI - analisam-se cartas em seções dedicadas aos leitores de jornais, capas de revistas, reportagens, artigos e crônicas. Assume-se uma classificação para a metalinguagem purista no país, nessa passagem de século, proposta por esta autora em pesquisa de maior fôlego: purismo nacionalista e purismo neoliberal ${ }^{1}$.

O lugar teórico que se privilegia são os estudos bakhtinianos do discurso, em especial a reflexão do círculo de Bakhtin sobre a tensão entre o mesmo/o diferente quando da produção de sentido. Nessa perspectiva, analisar o sentido do discurso significa lançar um olhar para sua constituição dialógica na grande temporalidade que envolve passado, presente e futuro (BAKHTIN, 2000). As memórias (do passado e do futuro, esta composta das antecipações da resposta do outro), são partes constitutivas do enunciado que é produzido:

Várias considerações e análises contidas neste artigo podem ser encontradas, expandidas, em Mendonça (2006a) - tese de doutorado inédita. 
Não há palavra que seja a primeira ou a última, e não há limites para o contexto dialógico (este se perde num passado ilimitado e num futuro ilimitado). Mesmo os sentidos passados, aqueles que nasceram do diálogo com os séculos passados, nunca estão estabilizados (encerrados, acabados de uma vez por todas). Sempre se modificarão (renovando-se) no desenrolar do subseqüente, futuro. Em cada um dos pontos do diálogo que se desenrola, existe uma multiplicidade inumerável, ilimitada de sentidos esquecidos, porém, num determinado ponto, no desenrolar do diálogo, ao sabor de sua evolução, eles serão rememorados e renascerão numa forma renovada (num contexto novo). Não há nada morto de maneira absoluta. Todo sentido festejará um dia seu renascimento. O problema da grande temporalidade. (BAKHTIN, 2000, p. 413)

Nas análises produzidas, aplica-se o conceito bakhtiniano de contrapalavra aos estudos do discurso ${ }^{2}$. O conceito pode ser entendido como sinônimo de compreensão responsiva e dá lugar, no dialogismo, a uma constante ressignificação. Dessa perspectiva, assume-se que, quando o sujeito enuncia/compreende, ele responde aos discursos dos outros, os quais constituem o seu - opera-se, diga-se assim, uma "incorporação constantemente ressignificada" do discurso do outro.

Mas o processo de ressignificação não se dá de forma livre, independente da língua ou do contexto sócio-histórico. O sentido do discurso é pensado na sua relação com o que é estável (a sua significação, composta por aspectos que a língua traz consigo em sua historicidade) e com o que o desestabiliza (o tema, entendido como o contexto sócio-histórico e até situacional em que se dá o processo de produção de sentido) (BAKHTIN/ VOLOCHINOV, 1988).

\section{A metalinguagem purista no Brasil}

Leite (1999) faz um estudo da configuração do purismo brasileiro a partir da segunda metade do século XIX. A autora propõe a distinção entre purismo discursivo metalingüístico e purismo discursivo, stricto sensu. Enquanto este não desencadeia metalinguagem e se realiza por meio de escolhas lexicais e sintáticas do falante, aquele se realiza metalingüisticamente. O objeto eleito por ela para análise será a metalinguagem purista, pela qual “(...) é possível recuperar posições ideológicas dos falantes diante de certos fatos

\footnotetext{
2 Para outros estudos bakhtinianos, nesta perspectiva, consultar Geraldi (1993, 2003).
} 
que implicam a defesa e preservação da história e da cultura do homem, pela língua que usa" (p. 50). A autora toma purismo como um fenômeno de preservação da norma, nem sempre ligado à correção - a relação entre purismo e correção é corrente na lingüística e encontra-se, por exemplo, em Camara Jr:

PURISMO - Atitude de extremado respeito às formas lingüísticas consagradas pela tradição do idioma (v.), que muitas vezes se assume na língua literária; a língua é considerada à maneira de uma água cristalina e pura, que não deve ser contaminada. Daí a hostilidade aos estrangeirismos (v.), aos neologismos (v.) e a todas as formas lingüísticas não autorizadas pelo uso literário tradicional. Essa atitude, adotada rigidamente, cerceia a capacidade expressiva. A lingüística ora vê o purismo literário com desconfiança, como um elemento de perturbação no manuseio espontâneo da língua (como acontece com a escola lingüística norte-americana), ora aconselha "um purismo inteligente, adaptado às evoluções necessárias” (DAUZAT, 1930, p. 8) (como é a orientação das escolas francesa, italiana e espanhola modernas). (CAMARA Jr., s/d, p. 323)

Toma-se aqui, como Leite (1999), o purismo como um fenômeno de preservação da norma. No entanto, é necessário precisar os significados de norma. A autora mostra que cada um dos diferentes purismos encontrados nos dados que analisou defende a preservação de um tipo específico de norma. Assim, ela distingue, na metalinguagem produzida no país a partir do século XIX, três tipos consecutivos de purismo:

1. O histórico ortodoxo (em que se buscava a preservação da norma prescritiva portuguesa);

2. O nacionalista (em que a norma a ser preservada era a objetiva praticada no Brasil);

3. O histórico heterodoxo (em que há um embate entre norma prescritiva e objetiva).

A autora concebe essas normas conforme Rey: "a norma lingüística denominada objetiva é aquela que é efetivamente praticada pelos falantes no uso espontâneo da língua, no registro culto ou popular. A norma prescritiva é a que está codificada nas gramáticas normativas" (LEITE, 1999, p. 27). 
Leite estuda, no que chama de purismo histórico ortodoxo, a polêmica lingüística travada entre Rui Barbosa e Ernesto Carneiro Ribeiro a respeito da redação do Projeto do Código Civil, no final do século XIX e início do $\mathrm{XX}$. Segundo a autora, a metalinguagem reacionária à mudança elaborada nessa época no Brasil, cuja “(...) ideologia aparente é a de que somente no passado reside a cultura e a pureza da língua” (p. 50), tem as mesmas características do purismo que vinha sendo praticado desde o século XVIII. No começo do século XX,

(...) as polêmicas lingüísticas revelam ter vigorado naquela fase a certeza de que a língua portuguesa devia ficar fixada no período clássico, tido como o de maior esplendor e beleza. (...) não se admitiam interferências de palavras estrangeiras, nem de palavras novas ou velhas. As palavras estrangeiras, especialmente francesas, representavam o perigo de transformar a língua, descaracterizá-la. As novas, desprestigiadas, eram negadas por desviarem a língua do caminho da perfeição. As velhas eram rechaçadas por fazerem parte de uma fase mais pobre da formação da língua. Enfim, tudo, no fundo, levava a um só caminho: preservar a tradição clássica do português. O purismo ortodoxo foi praticado para se alcançar esse objetivo. (LEITE, 1999, p. 242)

Quanto ao purismo nacionalista, Leite coloca como fundamental para compreendê-lo a metalinguagem produzida por Mário de Andrade, em que o nacionalismo se reflete como a negação da presença portuguesa na linguagem e a tentativa de levar à escrita uma linguagem mais próxima da que se usava no Brasil: "Neste período, solidificou-se o uso brasileiro e fezse também uma metalinguagem purista que o consagrou, trabalhando no sentido de preservá-lo" (p. 243). Sua ideologia aparente, segundo a autora, é a “(...) rejeição de um passado cultural que não está diretamente relacionado à sociedade” (p. 50).

Analisando a metalinguagem purista mais recente, a autora encontra o que chama de purismo heterodoxo a partir do exame de Manuais de Redação de jornais e de textos publicados em jornais e escritos por articulistas, cronistas e leitores. Conforme Leite, convivem nessa metalinguagem um fluxo inovador, “(...) representado pela atualização da língua padrão adequada ao uso brasileiro” ${ }^{3}$ (p. 243), isso no uso lingüístico que se faz na

\footnotetext{
3 A autora concebe língua padrão conforme Coseriu, segundo quem língua padrão é
} 
mídia, e um refluxo conservador que mostra uma resistência a esses novos usos de linguagem.

Essa metalinguagem também pode ser encontrada no corpus desta pesquisa:

Falar e escrever bem ajuda na hora de arrumar emprego, conseguir promoção e até para conquistar namorado ou namorada. Mas não vá exagerar na dose e virar um patrulheiro da língua, porque pega mal. (PAPAROUNIS, 2002)

Mas a verdade é que as empresas estão muito preocupadas com as escorregadelas e, em alguns casos, com os verdadeiros tombos que seus profissionais estão levando na hora de escrever ou mesmo falar em bom português. Não é raro encontrar executivos usando por aí expressões como "a nível de (sic) produção", ou "vou estar enviando (sic) o documento", ou ainda começando uma frase com algo como "Me (sic) informaram que as dúvidas seriam esclarecidas", entre outras pérolas. (SILVEIRA, 2002)

Na primeira citação, retirada de reportagem publicada pela revista Tudo, o locutor incorpora a norma objetiva, materializada nas expressões cotidianas "exagerar na dose", "pega mal", que revelam um estilo informal de linguagem, em um fluxo inovador no uso lingüístico; entretanto, mantém o purismo lingüístico ortodoxo, preso à norma prescritiva que postula os padrões do certo e errado, ao enunciar "Falar e escrever bem...."

Na segunda, trecho de reportagem da revista Você s/a, a questão da colocação pronominal que aparece na polêmica entre Rui Barbosa, em Réplica, e Ernesto Carneiro Ribeiro, em Tréplica (analisada por Leite, 1999) é atualizada (na polêmica, discute-se a inadequação de iniciar-se frase ou período com pronome átono), mas o estilo informal revela influência da norma objetiva, praticada pelos falantes no uso cotidiano: "escorregadelas", "verdadeiros tombos", "usando por aí".

\footnotetext{
"uma segunda língua comum que se estabelece por cima da língua comum (...), como forma idealmente unitária da mesma, pelo menos para aquelas tarefas e atividades (culturais, políticas, sociais, educacionais) que são (idealmente) tarefas e atividade de toda a comunidade idiomática. Com isso, a língua exemplar [ou língua padrão] confirma a coesão e a individualidade da comunidade correspondente a uma língua histórica e é a expressão mais eloqüente da unidade étnico-cultural da comunidade idiomática" (apud LEITE, 1999, p. 28).
} 
Propõe-se, neste artigo, partir do estudo de Leite (1999) e ampliar a discussão sobre a metalinguagem purista presente na imprensa nesta passagem do século. Nos discursos analisados (cartas em seções dedicadas aos leitores de jornais, capas de revistas, reportagens e artigos), foram encontradas duas grandes tendências, para as quais se propõe a seguinte classificação: purismo neoliberal e purismo nacionalista, ambas condicionadas por valores ideológicos materializados nos discursos, ora a ideologia neoliberal, ora a reação à globalização cultural e econômica.

Propõe-se ampliar o conceito de purismo nacionalista, tal como o concebe Leite (1999). Ao invés de pensá-lo necessariamente como uma atitude lingüística de preservação da norma objetiva brasileira por oposição ao purismo ortodoxo que buscava a preservação da norma prescritiva portuguesa, neste artigo ele é considerado um mecanismo que ajuda a sustentar a atitude nacionalista de exaltação do sentimento nacional, atitude de preferência pelo que é próprio da nação à qual se pertence.

Manifestações desse purismo são discursos que criticam o uso de estrangeirismos no Brasil, principalmente os anglicismos. É no contexto da acentuada globalização econômica e cultural pela qual os países vêm passando que se destaca essa metalinguagem. Ela já emergia entre os portugueses, que lutavam, no século XIX, contra o poderio cultural do francês, e parte do purismo encontrado nos documentos da época ilustram esse embate purista (LEITE, 1999). Essa metalinguagem, em Portugal, é mais antiga: já está presente em Leal Conselheiro, de D. Duarte, documento anterior ao século $\mathrm{XV}$,

(...) quando os vernáculos começaram a se estabelecer como línguas nacionais, em que há reação contra a cultura clássica latina. Nesse documento, a defesa da língua nacional surge na reação contra os empréstimos de termos alatinados ou de outra origem, pelos falantes do galego-português. (LEITE, 1999, p. 24)

No caso específico da luta contra os estrangeirismos no Brasil do final do século XX e início do século XXI, o purismo nacionalista, como a análise a seguir mostra, se constitui como uma reapropriação do purismo histórico ortodoxo, no sentido que lhe atribui Leite, em que se deseja ver preservada a norma prescritiva. No entanto, essa luta pela preservação dos valores da nação, centralizando-se nas questões relativas à língua nacional e/ou à exclusão de estrangeirismos, nesta pesquisa, pode manifestar-se também no 
purismo nacionalista como o propõe Leite, em que se busca a preservação da norma objetiva. Os românticos, como a análise a seguir mostra, lutavam contra um outro que era Portugal, na produção de sua identidade como nação, e aí se manifesta seu purismo nacionalista, na tentativa de preservar (e até produzir) uma norma nacional, na busca, para o português do Brasil, de uma língua mais pura utilizando o parâmetro da língua praticada no país. Neste caso, o purismo nacionalista se apóia na norma objetiva. É a essa tendência nacionalista relacionada ao uso lingüístico, ora apoiada na norma prescritiva, ora na norma objetiva, que se considera aqui purismo nacionalista.

\subsection{0 purismo como atitude lingüística historicamente produzida}

O purismo é uma atitude lingüística historicamente produzida: há uma rede de discursos puristas que se dissemina pela sociedade brasileira por conta do valor politicamente constituído da escrita, do livro e da sociedade letrada, por conta do valor dado historicamente às gramáticas tradicionais e aos discursos que são veiculados nas mídias. Essas vozes puristas são incorporadas em diversos espaços sociais, até na família, de forma que os sujeitos buscam "falar bem" - ou seja: estar de acordo com a cidade letrada, obter status com isso, conseguir se destacar e ser valorizado no social.

Assume-se o conceito de cidade letrada conforme propõe Rama (1985). Em ensaio que mostra como se deu o controle de populações na América espanhola e portuguesa, desde o início de sua colonização, o autor fala de cidades ordenadas, que buscavam "(...) organizar os homens dentro de uma repetida paisagem urbana” (p. 23), no interior das quais se localizavam cidades não menos amuralhadas que as regeram e as conduziram, as cidades letradas: “(...) o anel protetor do poder e o executor de suas ordens: uma plêiade de religiosos, administradores, educadores, profissionais, escritores e múltiplos servidores intelectuais. Todos os que manejavam a pena estavam estreitamente associados às funções do poder (...)” (p. 43).

Refletindo sobre a supremacia da cidade das letras ao longo da história da América Latina, Rama (1985, p. 49-50) a atribui “(...) ao paradoxo de que seus membros foram os únicos exercitantes da letra num meio desguarnecido de letras, os donos da escritura numa sociedade analfabeta (...)". Sobretudo a sociedade colonial brasileira, em comparação com as colônias hispano-americanas, carecia de sistema de educação e de difusão das letras. Só em 1757 é que o Marquês de Pombal, ao expulsar os jesuítas da Colônia, 
prescreve e oficializa o ensino de língua portuguesa no território brasileiro, tornando-o obrigatório - antes desse período, a educação estava confiada aos jesuítas, realizada em colégios religiosos. Ademais, até o século XIX, foi oficialmente proibida a implantação de imprensas no país, assim como a difusão de livros publicados no exterior. O Brasil precisou esperar também para ter uma universidade: data de 1920 a primeira instituição universitária brasileira, que reuniu as faculdades de Medicina e Direito (de 1832) e a Escola Politécnica (1894); em 1931 transforma-se em Universidade do Brasil e em 1945 passa a Universidade Federal do Rio de Janeiro (BERENBLUM, 2002). Esses dados são indicativos da pouca escolaridade da sociedade brasileira durante sua história, e do escasso acesso aos livros, o que acentua o poder da palavra escrita de uma pequena parcela da sociedade.

Rama (1985) também atribui a supremacia da cidade das letras à sacralização das letras, e por conseqüência, da escritura, dentro da tendência gramatológica da cultura européia. A cidade letrada era uma cidade escriturária que representava uma minoria. Assim, em situação minoritária dentro da sociedade, havia necessidade de exercer uma atitude defensiva dentro de um meio hostil. Isso, segundo Rama (1985, p. 57-58), ajuda a entender a

(...) fervorosa adesão letrada à norma cortesã peninsular e logo à Real Academia da Língua. (...) O uso dessa língua [escrita e "pura"] purificava uma hierarquia social, dava provas de uma proeminência e estabelecia um cerco defensivo em relação a um contorno hostil e, sobretudo, inferior.

O autor destaca que o manejo dessa língua minoritária, quase secreta, não somente definia essa cidade letrada para si mesma, mas também, defendendo e purificando essa língua, mantinha sua ligação com a metrópole, a qual sustentava seu poder. De acordo com Rama (1985, p. 61), o purismo lingüístico “(...) foi a obsessão do continente no transcurso de sua história”.

Silva Neto (1963) também destaca a extrema submissão literária e lingüística que ocorreu no Brasil desde fins do século XVIII com o desejo de a elite local "imitar a sociedade de além-mar" - os modelos supremos eram a corte de Lisboa e a Universidade de Coimbra.

Os puristas e os gramáticos exerceram uma fiscalização mais severa e temível que o da própria Inquisição... Condenar-se-ia tudo aquilo que não fosse rigorosamente 
cortado pelos figurinos da metrópole. Não se aceitavam as alterações, naturais e respeitáveis, que a língua assumira na América. (SILVA NETO, 1963, p. 71-72)

O autor destaca que a cidade letrada soube transformar-se quando necessário para continuar detentora do poder; temos como exemplo a "revolução" romântica, que buscou valorizar a linguagem popular, opondo-se ao padrão português. Além disso, a apropriação do domínio do popular e oral pela escrita produz deslocamentos que consagram novamente a escrita, produz a "folclorização" daquilo que é cultura popular.

A constituição da literatura, como um discurso sobre a formação, composição e definição da nação, haveria de permitir a incorporação de múltiplos materiais alheios ao círculo anterior das belas letras que emanavam das elites cultas, mas implicava, além disso, uma prévia homogeneização e higienização do campo, o que somente podia ser realizado pela escritura. A constituição das literaturas nacionais que se cumpre no final do século XIX é um triunfo da cidade das letras, que pela primeira vez em sua longa história, começa a dominar o seu contorno. (RAMA, 1985, p. 93)

Esse poder da escrita, associado à tradição gramatical do continente europeu seguida pela elite brasileira, é um fator que acentuou o purismo no país. É nesse sentido que se defende que ele seja historicamente produzido.

\section{O purismo nacionalista}

O purismo nacionalista do final do século XX e início do XXI constituise a partir da tradição gramatical e do discurso dos escritores românticos do século XIX, e se manifesta em gramáticas tradicionais e na mídia de referência.

Veja-se a metalinguagem de nossos escritores românticos. Conforme Pimentel Pinto (1978), Alencar, por sua relevância como romancista, foi tomado como símbolo do pensamento romântico sobre língua do Brasil. Buscou incorporar o tupi e formas populares de linguagem à sua produção literária, o que, para o autor, fazia parte da construção de uma literatura nacional. Tinha um plano ambicioso de revisão da língua e da literatura em língua portuguesa. Defendia os neologismos de fundamento estético, 
alguns estrangeirismos e velhas fontes da língua, tendo por objetivo principal romper com o passado português e com a atitude purista ortodoxa.

Criar termos necessários para exprimir os inventos recentes, assimilar-se aqueles que, embora oriundos de línguas diversas, sejam indispensáveis, e sobretudo explorar as próprias fontes, veios preciosos onde talvez ficaram esquecidas muitas pedras finas: essa é a missão das línguas cultas e seu verdadeiro classismo. (...)

Sem o arremedo vil da locução alheia e a imitação torpe dos idiotismos estrangeiros, devem as línguas aceitar algumas novas maneiras de dizer, graciosas e elegantes, que não repugnem ao seu gênio e organismo. (ALENCAR, 1978, p. 56)

Apesar das polêmicas de Alencar sobre língua terem sido apontadas como uma luta em proveito próprio - já que argumentava a favor do uso que ele mesmo desejava fazer da língua - e não para caracterizar o português realmente falado no Brasil (LEITE, 1999), elas têm um valor importante na metalinguagem romântica e no se chama aqui de purismo nacionalista. O outro de que se desejava distanciar, à época, era o português, então se buscava uma nova linguagem para expressar as idéias e as coisas da nova nação: esta incorpora galicismos e palavras provenientes do tupi, cria novos termos, tendo por objetivo constituir uma literatura própria, com estilo próprio para a nação em emergência. Nesse processo, Alencar busca valorizar um estilo diferente do dos clássicos portugueses. Isso pode ser visto quando responde a uma crítica do Dr. Henriques Leal, que o acusara de apresentar um estilo frouxo e desleixado - sem elos produzidos por conjunções - especialmente em O Guarani: “(...) aqueles que censuram minha maneira de escrever, saberão que não provém ela, mercê de Deus, da ignorância dos clássicos, mas de uma convicção profunda a respeito da decadência daquela escola" (ALENCAR, 1978, p. 84).

Nesse movimento de negação da linguagem literária clássica portuguesa, o escritor assume uma atitude purista nacionalista ao não querer ver a língua literária nacional "maculada" por aquilo que renega. Coloca-a como superior ao português ortodoxo, por supostamente expressar o modo de vida que se levava por aqui e os seus habitantes. Ainda: vê uma relação indissolúvel entre língua e nação: 
Cumpre não esquecer que o filho do Novo Mundo recebe as tradições das raças indígenas e vive ao contato de quase todas as raças civilizadas que aportam a suas plagas trazidas pela emigração. (...)

Os operários da transformação de nossas línguas são esses representantes de tantas raças, desde a saxônica até a africana, que fazem neste solo exuberante amálgama do sangue, das tradições e da língua. (...)

Sempre direi que seria uma aberração de todas as leis morais que a pujante civilização brasileira, com todos elementos de força e grandeza, não aperfeiçoasse o instrumento das idéias, a língua.

Todos os povos de gênio musical possuem uma língua sonora e abundante. O Brasil está nessas condições; a influência nacional já se fez sentir na pronúncia muito mais suave do nosso dialeto. (ALENCAR, 1978, p. 74)

É importante destacar o papel que o escritor se atribui nesse processo de constituição do nacional via produção literária. Em Gonçalves Dias, a problemática da intermediação entre língua popular e escritor na produção literária fica explícita, problemática que será largamente abordada por Alencar. Este autor vê no escritor um papel central na "transposição" da linguagem popular para a obra literária - é ele quem "depura-a de sua vulgaridade" (ALENCAR, 1978, p. 58); são os bons escritores que "talham e pulem o grosseiro dialeto do vulgo, como o escultor cinzela o rudo troço de mármore e dele extrai o fino lavor", são eles que "vão corrigindo e limando [a gramática rude e incoerente saída da infância do povo]" (ALENCAR, 1978, p. 74). Por seu turno, é o povo que tem a soberania para modificar a gramática da língua que ele usa, o germe da mudança está no "espírito popular, no falar do povo" (ALENCAR, 1870, p. 75). E ao público leitor cabe a sanção ou o aplauso das ousadias de linguagem perpetradas pelos escritores (ALENCAR, 1978). O papel do escritor fica bem marcado neste período de construção da nação, pós-independência política, mas também aparece em momentos posteriores. Conforme Pimentel Pinto (1978, p. XXXI), Machado de Assis reconhece ao escritor o papel de depurador das criações populares, mas no sentido de dar-se (como escritor) o direito de rejeitar inovações.

Observa-se que já se encontrava, nos 1800, uma polêmica sobre ser nacional e o que esse processo se relacionava com a língua nacional, polêmica que foi ressignificada de forma específica na passagem do século XX para o XXI. Abordemos um viés da polêmica que o uso de anglicismos suscitou na 
sociedade brasileira na passagem do século XX para o século XXI: o Projeto de Lei $n^{\circ} 1676 / 99$, proposto pelo deputado federal Aldo Rebelo (PCdoB - SP) em 1999, visando legislar sobre o planejamento lingüístico e a política lingüística no país ${ }^{4}$.

Veja-se o discurso de escritores brasileiros sobre esse projeto e como eles dialogam com o discurso dos românticos.

Ariano Suassuna (2000a, 2000b) discute, em crônicas veiculadas na Folha de S. Paulo, a problemática do uso do inglês para a vida nacional. A atitude do cronista em relação à defesa da língua e de outros aspectos da cultura nacional pode ser comparada à do poeta romântico "eleito", aquele que deveria trazer a Boa Nova, os valores sagrados (no caso de Gonçalves de Magalhães, em "Lede", os valores que vinham da Europa), aquele que se atribuía a tarefa de construir a Pátria. Mas no final do século XX e início do XXI, a função do escritor é proteger a cultura nacional dos avanços da globalização cultural e econômica; e a identidade se produz no discurso de Suassuna pela exclusão do outro (no caso, a língua inglesa e seu falante). Se, no processo de construção de identidade nacional, o senso comum produz um inimigo, na conjuntura atual trata-se do norte-americano que explora a nação, induz ao consumo daquilo que "descaracteriza" o povo e sua cultura e introduz na língua portuguesa itens lexicais que a "desfiguram" - já no purismo nacionalista romântico, tratava-se de se proteger da tradição portuguesa.

Pode-se imaginar (...) como fico preocupado ao ver a língua portuguesa desfigurada, como está acontecendo. Sei perfeitamente (e o deputado Aldo Rebelo sabe também) que um idioma é uma coisa viva e pulsante. Não queremos isolar o português, que, como acontece com qualquer outra língua, se enriquece com as palavras e expressões das outras. Mas elas devem ser adaptadas à forma $\mathrm{e}$ ao espírito do idioma que as acolhe. Somente assim é que deixam de ser

\footnotetext{
Toma-se aqui esses conceitos como o propõe (CALVET, 2002, p. 145): "Chamaremos política lingüística um conjunto de escolhas conscientes referentes às relações entre língua(s) e vida social, e planejamento lingüístico a implementação prática de uma política lingüística, em suma, a passagem ao ato. Não importa que grupo pode elaborar uma política lingüística: fala-se, por exemplo, em "políticas lingüísticas familiares" (...). Mas, num campo tão importante quanto as relações entre língua e vida social, só o Estado tem o poder e os meios de passar ao estágio do planejamento, de pôr em prática suas escolhas lingüísticas."
} 
mostrengos que nos desfiguram e se transformam em incorporações que nos enriquecem. (...) (SUASSUNA, 2000a)

O papel do escritor, no discurso de Suassuna, é o de ajudar a livrar a nação dessa influência tida como negativa. Esse novo colonizador não deveria ser integrado às produções culturais da nação, e a língua deveria manter-se livre dessa influência que a descaracteriza. A língua portuguesa é tomada pelo escritor como um instrumento de representação da nação, em suas especificidades culturais, e deve ser mantida como tal. Está clara, no discurso de Suassuna, a relação entre língua e aspectos culturais e políticos, relação que o autor destaca ao colocar a defesa do idioma como parte da luta "contra a entrega do nosso território, da nossa economia, da nossa identidade cultural" (SUASSUNA, 2000b). Sua "desfiguração" com o uso do inglês seria iminente, por isso deveria ser objeto de uma política de defesa e preservação.

O purismo nacionalista também se materializa em discurso de Lygia Fagundes Telles, comentando o referido projeto em O Estado de S. Paulo: "Uma extraordinária arma para impedir a colonização da língua portuguesa", "Para a escritora Lygia Fagundes Telles, nos últimos anos muitos abusos foram cometidos. 'Precisávamos de algo para proteger a língua portuguesa”. (FORMENTI, 2000).

Se os nossos românticos, representados pela figura de Alencar, manifestavam seu purismo nacionalista rejeitando o português clássico e buscando uma forma mais nacional de produção artística, o escritor do final do século XX e começo do XXI reage contra a dominação imposta pela cultura e economia dos EUA, e com base nesse novo "inimigo", ressignifica o discurso purista nacionalista dos românticos. O que está em jogo é a identidade nacional, identidade que deve ser reconstituída constantemente pelo escritor, que se atribui essa missão. Veja-se como se processa a ressignificação nesse caso: trata-se de uma paráfrase do discurso nacionalista romântico ao retomar a problemática da "necessidade" de proteger a língua nacional; porém, esse discurso tem um outro alvo de ataque e uma nova postura política frente a esse alvo. Considerando-se a proposta bakhtiniana para se pensar o sentido, pode-se dizer que a memória discursiva carrega significações que são incorporadas e rearranjadas em função do novo contexto político-econômico que domina as relações de sentido produzidas pelos sujeitos. 
Esse purismo também se constitui nas práticas discursivas produzidas pelos gramáticos brasileiros ao longo do século XX (MENDONÇA, 2006b). Nesses instrumentos lingüísticos ${ }^{5}$, encontram-se coincidências discursivas quanto ao uso das palavras estrangeiras: ele é tido como vicioso quando há um correspondente em língua vernácula; há a necessidade de demarcação/ separação do estrangeirismo com as aspas; há a necessidade de domesticação do estrangeirismo pela língua importadora, ou seja, a conformação daquele ao sistema lingüístico desta; há uma reação ao estrangeirismo que representa perigo à unidade lingüística nacional (na primeira metade do século XX, a língua estrangeira que representa esse perigo é o francês; na segunda metade, é o inglês). Vejam-se essas coincidências discursivas em dois fragmentos de gramáticas - a primeira, de 1936; a segunda, de 1998:

(...) as palavras e expressões francesas vão tomando de assalto o nosso vocabulário, dele desterrando vozes e expressões castiças. Isto se justifica pela posição saliente que ocupa a França na moderna civilização. Os escritores brasileiros contemporâneos, antes de se aperceberem do necessário cabedal de conhecimento do idioma pátrio, põem-se a ler as obras dos escritores franceses, viciando o estilo. (...)

É galicismo léxico o emprego desnecessário de uma palavra francesa em português, ou o emprego de uma palavra portuguesa com a acepção particular que tem no francês. (...)

Estendemo-nos um pouco na enumeração das palavras francesas para acautelarmos contra o seu emprego os menos experientes. Usá-las, quando delas não haja necessidade, ou mesmo neste caso, sem as acomodar ao gênio da língua, constitui vício de linguagem. (COUTINHO, 1973, p. 195-196) ${ }^{6}$.

(...) Quando mantêm a grafia da língua de origem, as palavras devem ser escritas entre aspas (na imprensa, devem surgir em destaque - normalmente itálico: shopping center, show, stress).

${ }^{5}$ Auroux considera as gramáticas como instrumentos lingüísticos, colocando em pauta seu papel político: concebe sua produção como um processo de gramatização que possibilita a dominação de povos nas colônias européias, a partir do Renascimento, por fornecer um modelo de descrição de suas línguas, modelo europeu advindo da tradição greco-romana, transferido às línguas européias e posteriormente às das populações colonizadas. Essa instrumentação lingüística, conceito proposto pelo autor, "mudou profundamente a ecologia da comunicação humana e deu ao Ocidente um meio de conhecimento/dominação sobre as novas outras culturas do planeta" (AUROUX, 1992, p. 8-9).

${ }^{6}$ A primeira edição dessa gramática é de 1936. 
Atente para o fato de que os empréstimos lingüísticos só fazem sentido quando necessários. É o que ocorre quando surgem novos produtos ou processos tecnológicos. Ainda assim, esses empréstimos devem ser submetidos ao tratamento de conformação aos hábitos fonológicos e morfológicos da língua portuguesa. São condenáveis abusos de estrangeirismos decorrentes de afetação de comportamento ou de subserviência cultural. A imprensa e a publicidade não resistem à tentação de utilizar a denominação estrangeira de forma apelativa, como em expressões do tipo os teens (por adolescentes) ou high technology system (sistema de alta tecnologia). (CIPRO NETO, INFANTE, 1998, p. 109-110).

O purismo nacionalista produzido discursivamente nas gramáticas, ao longo do século XX, é atualizado na imprensa na voz do leitor do grande jornal, do político e do jornalista. Realiza-se a um diálogo em que, novamente, tem-se um processo parafrástico.

\section{Estrangeirismo}

Vejo nos jornais, agora que se fala tanto em segurança no trânsito, o emprego insistente de "kit" de primeiros socorros, que todo motorista deve ter em seu porta-luvas.

Impressiona-me a facilidade com que a imprensa assimila expressões do idioma inglês em substituição a corretíssimos termos do vernáculo, muito mais ricos e expressivos, notadamente no caso do tal "kit", quando temos variados recursos para expressar essa idéia.

No entanto, a despeito de termos como, digamos, estojo de ferramenta, estojo escolar, estojo de primeiros socorros, jogo de ferramentas, jogo de cama e de mesa, conjunto de chá e café, vamos engolindo servilmente o paupérrimo kit, agora já sem aspas porque introduzido no linguajar escrito e falado.

Esse jornal, que, sem favor algum, é dos grandes formadores de opinião, bem que poderia iniciar um movimento de valorização de nosso idioma, recomendando a seus redatores que limitassem o emprego de estrangeirismos, usando-os somente quando não houver o correspondente no português. (CONTAR, 1999)

A carta do leitor acima, enviada ao jornal Folha de S. Paulo, retoma o discurso dos gramáticos quando pede restrição ao uso de palavras estrangeiras se houver termos correspondentes em português e critica a não-utilização de aspas demarcando essas palavras. 
O fragmento de artigo a seguir, de autoria do deputado Aldo Rebelo, em polêmica com Carlos A. Faraco no mesmo jornal, também parafraseia o discurso dos gramáticos, elogiando a acomodação das palavras estrangeiras à estrutura da língua portuguesa e criticando o uso de palavras inglesas quando há correspondentes em português.

Mesmo futebol, que tomamos do inglês, tivemos a sabedoria de adaptá-lo na pronúncia e na escrita, mudando não apenas vogais, mas também a entonação da expressão inglesa. É o caso de toalete, restaurante e milhares de francesismos que acomodamos ao nosso falar e a nossa escrita.

"Sale", "delivery" - O projeto de lei no 1.676/99, de minha autoria, longe da xenofobia de que é acusado ou de rejeitar contribuições de línguas estranhas (...), tão-somente deseja a valorização da nossa. Por que substituir liquidação ou "queima" das lojas populares pelo pedante "sale", para não falarmos de "delivery", "playoffs", "valet parking", "drive thru"? (REBELO, 2001)

Analisando-se como se produz a paráfrase, nesse caso, pode-se afirmar que, se o discurso dos gramáticos aponta a importância de "cuidar da língua", livrando-a de influências "nefastas" de outras línguas, e produz uma prática de padronização do uso da língua, o discurso do político destaca a importância de "cuidar da nação", e a prática produzida é o planejamento lingüístico. Considerando-se a incorporação do fazer do discurso, ou seja, a incorporação de suas práticas, a seus efeitos de sentido, pode-se dizer que a metalinguagem purista do político ressignifica a metalinguagem dos gramáticos.

Já do lugar do jornalista, quando se fala sobre o projeto do deputado Rebelo, emana um discurso purista que embasa sua semântica na "democracia" - apesar de se atualizar o discurso de crítica ao uso da palavra estrangeira, argumenta-se a favor do direito de o brasileiro usar a língua como quiser. Veja-se o caso de fragmentos do editorial a seguir.

\section{PORTUGUÊS A FÓRCEPS}

(...) É um despropósito a idéia de tentar regular o que as pessoas escrevem e falam. Pelo projeto, do deputado Aldo Rebelo (PC do B-SP), mesmo estrangeiros que residam no Brasil há mais de um ano estão obrigados a usar o português no trabalho. (...) 
Da mesma forma que os totalitarismos falharam em tentar controlar o que a população pensava, não há modo de regular o que as pessoas dizem ou escrevem, pelo menos não durante muito tempo.

Há, por certo, um uso exagerado de estrangeirismos em locais como os shopping centers. Mas o máximo que se pode fazer nesse caso é lamentar o mau gosto. $\mathrm{O}$ culto da língua não pode ser imposto de cima. Ele depende de disposições coletivas, de leitura, de educação de qualidade. E é no mínimo pouco democrático transformar em lei o gosto da Academia Brasileira de Letras. (EDITORIAL, 2001)

O fluxo discursivo da metalinguagem purista nacionalista se esgarça, na voz do jornalista, ao sabor da "modernidade democrática" (principalmente quando, do lugar do jornalista, afirma-se que o projeto de Aldo Rebelo representa um entrave ao "livre direito" de expressão). Entretanto, ainda se prega a liberdade vigiada do uso lingüístico ditado pelas gramáticas tradicionais, que são o espaço privilegiado da produção do "bem dizer", do "bom gosto".

\section{0 purismo neoliberal}

Também o purismo neoliberal tem suas raízes no discurso gramatical tradicional, que ele parafraseia (privilegia-se a correção, a clareza, em suma, o "bom uso" da língua). É uma paráfrase que se adapta ao contexto de enunciação do discurso, em que os valores sociais convergem para o objetivo de obter sucesso profissional.

O neoliberalismo, no contexto mundial, surge com a crise capitalista do início dos anos 70, acompanhada da crise do Estado de Bem-Estar. O Brasil, porém, viveu o impacto neoliberal de modo retardatário: somente em 1994 é que há a refundação liberal do Estado, no governo de Fernando Henrique Cardoso. Chauí (2001), em resumo crítico das recentes linhas político-econômicas, destaca as seguintes características do neoliberalismo:

A nova forma de acumulação do capital se caracteriza pela desintegração e desqualificação da mão-de-obra, aceleração do turnover da produção, do comércio e do consumo pelo desenvolvimento das técnicas de informação e distribuição, proliferação do setor de serviços, crescimento da economia informal e paralela (como resposta ao desemprego estrutural) e novos meios de prover os serviços 
financeiros (desregulação econômica e formação de grandes conglomerados financeiros que formam um único mercado mundial com poder de coordenação financeira). (CHAUÍ, 2001, p. 21)

Essa política econômica afeta diretamente a relação do homem contemporâneo com o trabalho. Há o desemprego estrutural gerado pela introdução de automação e pela “(...) velocidade da rotatividade da mão-de-obra, que se torna desqualificada e obsoleta muito rapidamente em decorrência da velocidade das mudanças tecnológicas" (CHAUÍ, 2001, p. 19); e a terceirização estrutural, que, ampliando o setor de serviços, fragmenta o trabalho em tarefas terceirizadas e enfraquece a noção de "classe operária". Segundo a autora, um subproduto do ideário neoliberal é o ideário pós-moderno, que tem, entre seus traços principais, a insegurança, esta gerada pelas incertezas e violências institucionalizadas pelo mercado.

Segundo Boito (2002), os pilares da política neoliberal podem ser compreendidos como uma série de três círculos concêntricos: o círculo externo e maior representa a política de desregulamentação do mercado de trabalho e de redução dos direitos sociais; o círculo intermediário, a política de privatização; e o círculo menor e central, a abertura comercial e financeira. Os interesses da grande maioria dos trabalhadores, segundo o autor, ficam do lado de fora desses três círculos, visto que tais interesses não são contemplados pelo neoliberalismo.

Nesse processo de insegurança no mercado de trabalho, também os estratos médios da estrutura sócio-econômica se vêem ameaçados - há um aumento na concorrência por cargos que exigem profissionais capacitados. É nesse contexto histórico que são produzidos discursos que buscam na língua - ou no que a mídia chama de "norma culta" - uma ferramenta para suplantar as dificuldades individuais de acesso aos bens, aos serviços e ao emprego. Essa é uma "realidade prática" de uso da língua, a qual possibilitaria ao profissional distinguir-se da maioria ou, ao menos, atingir aquilo que minimamente se esperaria do profissional capacitado: um "bom uso" da língua. No modelo político-ideológico do neoliberalismo, supervaloriza-se o sucesso pessoal/individual, em detrimento da "coletivização" (com

7 O conceito de norma culta tem sido utilizado, no senso comum, como sinônimo daquela presente nos instrumentos lingüísticos como gramáticas e dicionários. Mas, para os sociolingüistas brasileiros, metodologicamente, norma culta é considerada a norma utilizada por falantes que possuem nível universitário. 
suporte na classe social, nos interesses sociais, na busca de um bem-estar comum); o sucesso buscado à exaustão seria fruto do esforço de cada um, não das condições sociais a que teve acesso o indivíduo.

É certo que a norma prescritiva tem sido instrumento de exercício de poder ao longo da história brasileira, como se argumenta no item 1 deste artigo. Portanto, dominar a "norma culta" já era recurso necessário para exercer atividades profissionais privilegiadas no contexto social. Assim, os enunciados que constituem o purismo neoliberal não são novos. Entretanto, no contexto histórico por que o país passa, essa "norma culta" explicita-se na mídia como instrumento necessário para a ascensão social ou manutenção de status no mercado de trabalho.

Vejam-se enunciados, presentes em capas de revista, que manifestam esse tipo de purismo, no qual o "bom uso da língua" está associado ao sucesso profissional: "O brasileiro tem dificuldade de se expressar corretamente. Mas está fazendo tudo para melhorar, porque precisa disso na profissão, nos negócios e na vida social” (VEJA, 2001); “O inglês virou obrigação. Já o português pode ser seu diferencial" (VOCÊ S/A, 2002b); "Falar e escrever bem é a nova preocupação do brasileiro que quer crescer na profissão, fazer negócios e subir na vida" (TUDO, 2002).

Essa relação entre uso da língua e sucesso profissional aparece de forma exaustiva nas capas da revista VocêS/A, que focalizam continuadamente a necessidade de "expressar-se bem" para conseguir sucesso nas exposições orais - "Faça melhor: Reinaldo Polito ensina como fazer uma palestra de última hora" (2002a); "Faça melhor: Como vender sua idéia em 10 slides" $(2003)^{8}$; "O que fazer antes, durante e depois que falar em público" (2004). Todos esses discursos convergem na busca do sucesso profissional a partir do uso lingüístico. Nas capas dessa revista, a língua é, como o traje ou a aparência do profissional, sua porta de entrada no mercado de trabalho.

\section{Conclusão}

Os tipos de metalinguagem purista identificados neste artigo não esgotam as manifestações puristas presentes nas mídias no final do século XX e início de XXI. O objetivo aqui foi analisar as manifestações que estiveram em evidência no período estudado. Como elas não somente refletem, mas

\footnotetext{
8 No sumário online desse número da revista, temos a seguinte chamada: "Como vender sua idéia em 10 slides: aprenda a fazer uma apresentação que vai direto ao assunto”.
} 
também refratam o contexto histórico em que se constituem, ajudam a produzir uma realidade em que a língua se constitui como um "instrumento" político/econômico extremamente importante.

$\mathrm{Na}$ metalinguagem do purismo nacionalista que critica o uso de anglicismos, a língua nacional, patrimônio cultural por excelência, é tomada como objeto de salvação/perdição da cultura nacional. Esses discursos dialogam com a memória discursiva em que se dá a produção da nação através da constituição de uma língua nacional que reflete a nação, seu jeito de ser e viver, de uma língua nacional pura e homogênea. Já no purismo neoliberal, a língua é representada como instrumento de ascensão social e de manutenção de status sócio-econômico.

Como outras metalinguagens puristas, essas são extremamente excludentes - o purismo nacionalista, ao valorizar o nacional, ou se faz esquecerem suas diferenças, ou as torna desigualdades; o purismo neoliberal produz a idéia de que aqueles que desejarem terão acesso à norma-padrão e, por isso, coloca um véu sobre o fato de que as políticas públicas aplicadas à educação produzem uma realidade de exclusão e de desigualdades.

\section{Referências Bibliográficas}

ALENCAR, José de. Poscrito a Diva. In PIMENTEL PINTO, Edith. O português do Brasil: textos críticos e teóricos, 1 - 1820/1920, fontes para a teoria e a história. Rio de Janeiro: Livros Técnicos e Científicos; São Paulo: Ed. da Universidade de São Paulo, 1978.

Bênção Paterna. In PIMENTEL PINTO, Edith. O português do Brasil: textos críticos e teóricos, 1 - 1820/1920, fontes para a teoria e a história. Rio de Janeiro: Livros Técnicos e Científicos; São Paulo: Ed. da Universidade de São Paulo, 1978.

. Pós-Escrito à $2^{\mathrm{a}}$. ed. de Iracema. In PIMENTEL PINTO, Edith. O português do Brasil: textos críticos e teóricos, 1 - 1820/1920, fontes para a teoria e a história. Rio de Janeiro: Livros Técnicos e Científicos; São Paulo: Ed. da Universidade de São Paulo, 1978.

AUROUX, S. A revolução tecnológica da gramatização. Campinas: Editora da Unicamp, 1992.

BAKHTIN/VOLOCHINOV. Marxismo e filosofia da linguagem. Tradução de Michel Lahud e Yara F. Vieira. 4ª ed. São Paulo: Hucitec, 1988. 
BAKHTIN, M. Estética da criação verbal. 3a . ed. São Paulo: Martins Fontes, 2000.

BERENBLUM, Andrea. A invenção da palavra oficial: identidade e língua nacional em tempos de globalização. Tese apresentada ao curso de pósgraduação em Educação da Universidade Federal Fluminense. Niterói (RJ), 2002.

BOITO Jr., Armando. Neoliberalismo e burguesia no Brasil. Disponível em http://paje.fe.usp.br/ mbarbosa/nlboito.doc. Acesso em 11 jan. 2006.

CALVET, Louis-Jean. Sociolingüística: uma introdução crítica. Tradução de Marcos Marcionilo. São Paulo: Parábola, 2002.

CAMARA Jr., J. Mattoso. Dicionário de filologia e gramática: referente à língua portuguesa. $4^{\mathrm{a}}$. ed. Rio de Janeiro: J. Ozon Editor, s/d.

CHAUÍ, Marilena. Escritos sobre a universidade. São Paulo: Ed. UNESP, 2001.

CIPRO NETO, Pasquale, INFANTE, Ulisses. Gramática da língua portuguesa. São Paulo: Scipione, 1998.

CONTAR, Alberto. Carta. Folha de São Paulo, São Paulo, 31 jan. 1999. Painel do Leitor.

COUTINHO, Ismael de Lima. Pontos de gramática histórica. 6a. ed. Rio de Janeiro: Livraria Acadêmica, 1973.

DIAS, Gonçalves. Carta ao Dr. Pedro Nunes Leal. In PIMENTEL PINTO, Edith. O português do Brasil: textos críticos e teóricos, 1 - 1820/1920, fontes para a teoria e a história. Rio de Janeiro: Livros Técnicos e Científicos; São Paulo: Ed. da Universidade de São Paulo, 1978.

EDITORIAL. Português a fórceps. Folha de São Paulo, São Paulo, 30 mar. 2001. p. A2.

FORMENTI, Lígia. Abuso de estrangeirismos causa polêmica. O Estado de S. Paulo, São Paulo, 26 mar 2000, p. A20.

GERALDI, João Wanderley. Portos de passagem. $2^{\text {a }}$. ed. São Paulo: Martins Fontes,1993.

. Depois do "show", como encontrar encantamento? Cadernos de Estudos Lingüísticos, Campinas, (44): 251-261, Jan./Jun. 2003. 
LEITE, Marli Quadros. Metalinguagem e discurso: a configuração do purismo brasileiro. São Paulo: Humanitas/FFLCH/USP, 1999.

MAGALHÃES, Gonçalves de. Lede. In: PINTO, Edith Pimentel. O português do Brasil: textos críticos e teóricos, 1 - 1820/1920, fontes para a teoria e a história. Rio de Janeiro: Livros Técnicos e Científicos; São Paulo: Ed. da Universidade de São Paulo, 1978, p.13-16.

MENDONÇA, Marina Célia. MENDONÇA, Marina Célia. A luta pelo direito de dizer a língua: a lingüística e o purismo lingüístico na passagem do século XX para o século XXI. Tese de doutorado defendida no Instituto de Estudos da Linguagem da UNICAMP (Campinas - SP). Fevereiro de 2006. (2006a)

Discursos sobre o estrangeirismo: um enfoque em suas contradições. In: BERTOLDO, E. S., MUSSALIM, F. (orgs.) Análise do discurso: aspectos da discursividade no ensino. Goiânia: Trilhas Urbanas, 2006b.

PAPAROUNIS, Demetrius. O valor do bom português. Tudo, edição n. 60, 22 mar. 2002, p. 32-37.

PIMENTEL PINTO, Edith. Introdução. In: O português do Brasil: textos críticos e teóricos, 1 - 1820/1920, fontes para a teoria e a história. Rio de Janeiro: Livros Técnicos e Científicos; São Paulo: Ed. da Universidade de São Paulo, 1978. p. XV-LVIII.

RAMA, Angel. A cidade das letras. Tradução de Emir Sader. São Paulo: Brasiliense, 1985.

REBELO, Aldo. Projeto de Lei no. 1676.

A Intriga das Línguas. Folha de São Paulo, São Paulo, 13 maio 2001. Mais!, p. 22-23.

SILVA NETO, Serafim da. Introdução ao estudo da língua portuguêsa no Brasil. 2. ed. Rio de Janeiro: Instituto Nacional do Livro, 1963.

SILVEIRA, Mauro. Português: que língua é essa? Você S/A, 27 nov. 2002.

SUASSUNA, Ariano. Um projeto de lei. Folha de São Paulo, São Paulo, 25 abr. 2000a. Caderno Ilustrada.

. Uso de palavras estrangeiras. Folha de São Paulo, São Paulo, 31 jul. 2000b. Caderno Ilustrada. 
TUDO. Capa. N. 60, 22 mar. 2002.

VEJA. Capa. São Paulo: Ed. Abril, 07 nov. 2001.

VOCÊS/A. Capa. São Paulo: Ed. Abril, set. 2002a.

VOCÊS/A. Capa. São Paulo: Ed. Abril, out. 2002b.

VOCÊS/A. Capa. São Paulo: Ed. Abril, jan. 2003.

VOCÊS/A. Capa. São Paulo: Ed. Abril, jun. 2004. 